\title{
Ultrastructure of the Odontocete Organ of Corti: Scanning and Transmission Electron Microscopy
}

\author{
Maria Morell, ${ }^{1,2}$ Marc Lenoir, ${ }^{3}$ Robert E. Shadwick, ${ }^{2}$ Thierry Jauniaux, ${ }^{4}$ Willy Dabin, ${ }^{5}$ Lineke Begeman, ${ }^{6}$ \\ Marisa Ferreira, ${ }^{7}$ Iranzu Maestre, ${ }^{8}$ Eduard Degollada, ${ }^{9}$ Gema Hernandez-Milian, ${ }^{10}$ Chantal Cazevieille, ${ }^{11}$ \\ José-Manuel Fortuño, ${ }^{12}$ Wayne Vogl, ${ }^{13}$ Jean-Luc Puel, ${ }^{3}$ and Michel André ${ }^{1 *}$ \\ ${ }^{1}$ Laboratory of Applied Bio-Acoustics, Technological Center of Vilanova i la Geltrú, Technical University of Catalonia-Barcelona Tech, \\ 08800 Vilanova i la Geltrú, Barcelona, Spain \\ ${ }^{2}$ Zoology Department, The University of British Columbia, V6T 1 Z4 Vancouver, Canada \\ ${ }^{3}$ National Institute of Health and Medical Research U1051, Institute Neurosciences Montpellier, Saint Eloi Hospital, 34091 Mont- \\ pellier cedex 5, France \\ ${ }^{4}$ Department of Veterinary Pathology, University of Liège, 4000 Liège, Belgium \\ ${ }^{5}$ Center for Marine Mammal Research, University of La Rochelle, 17000 La Rochelle, France \\ ${ }^{6}$ Department of Pathobiology, Faculty of Veterinary Medicine, Utrecht University, 3508 TD Utrecht, The Netherlands \\ ${ }^{7}$ Portuguese Wildlife Society/Center of Molecular and Environmental Biology, Department of Biology, University of Minho, Gualtar \\ Campus, 4710-057 Braga, Portugal \\ ${ }^{8}$ AMBAR, Society for the Study and Conservation of Marine Fauna, 48014 Bilbao, Spain \\ ${ }^{9}$ EDMAKTUB Association for the Study and Disclosure of Aquatic Environment, 08034 Barcelona, Spain \\ ${ }^{10}$ School of Biological, Earth and Environmental Sciences, University College Cork, Cork, Ireland \\ ${ }^{11}$ Regional Center for Cellular Imaging Resources, 34091 Montpellier cedex 5, France \\ ${ }^{12}$ Institute of Marine Sciences, Spanish National Research Council, 08003 Barcelona, Spain \\ ${ }^{13}$ Department of Cellular and Physiological Sciences, The University of British Columbia, V6T 1 Z4 Vancouver, Canada
}

\section{ABSTRACT}

The morphological study of the Odontocete organ of Corti, together with possible alterations associated with damage from sound exposure, represents a key conservation approach to assess the effects of acoustic pollution on marine ecosystems. By collaborating with stranding networks from several European countries, 150 ears from 13 species of Odontocetes were collected and analyzed by scanning (SEM) and transmission (TEM) electron microscopy. Based on our analyses, we first describe and compare Odontocete cochlear structures and then propose a diagnostic method to identify inner ear alterations in stranded individuals. The two species analyzed by TEM (Phocoena phocoena and Stenella coeruleoalba) showed morphological characteristics in the lower basal turn of high-frequency hearing species. Among other striking features, outer hair cell bodies were extremely small and were strongly attached to Deiters cells. Such morphological characteristics, shared with horseshoe bats, suggest that there has been convergent evolution of sound reception mechanisms among echolocating species. Despite possible autolytic artifacts due to technical and experimental constraints, the SEM analysis allowed us to detect the presence of scarring processes resulting from the disappearance of outer hair cells from the epithelium. In addition, in contrast to the rapid decomposition process of the sensory epithelium after death (especially of the inner hair cells), the tectorial membrane appeared to be more resistant to postmortem autolysis effects. Analysis of the stereocilia imprint pattern at the undersurface of the tectorial membrane may provide a way to detect possible ultrastructural alterations of the hair cell stereocilia by mirroring them on the tectorial membrane. J. Comp. Neurol. 000:000-000, 2014.

(C) 2014 Wiley Periodicals, Inc.

INDEXING TERMS: inner ear; cochlea; cetacean; morphology; acoustic trauma

Grant sponsor: the Spanish Ministry of the Environment; Grant number: 083/SDGTB/2007; Grant sponsor: Agency for Administration of University and Research Grants (AGAUR; Generalitat of Catalonia) fellowships; Grant sponsor: Canadian Natural Sciences and Engineering Research Council Discovery and Accelerator grants.

*CORRESPONDENCE TO: Michel André, Avda, Rambla exposició s/n 08800-Vilanova i la Geltrú, Barcelona, Spain. E-mail: michel.andre@upc.edu

(C) Wiley Periodicals, Inc.
Received April 10, 2013; Revised September 26, 2014; Accepted September 26, 2014.

DOI 10.1002/cne.23688

Published online Month 00, 2014 in Wiley Online Library (wileyonlinelibrary.com) 
The ecological and physiological significance of noise effects on toothed whales (order Cetacea, suborder Odontoceti) has recently been recognized (Richardson et al., 1995) because of their vital dependence on acoustic information and their role as apex marine predators. Although some of the physiological damage caused by sound has been observed in organs not directly related to the acoustic pathways (Jepson et al., 2003), most lesions are expected to affect hearing, particularly the organ of Corti and its associated hair cells (Lurie et al., 1944).

In previous studies on terrestrial mammals, structural alterations of the organ of Corti have been found as a consequence of sound exposure. These consist of: 1) changes in the hair cell stereocilia (mainly fusion, size reduction, buckling, formation of "giant" hairs, and disappearance of hairs; Bredberg et al., 1972; Engstrom et al., 1984); 2) degeneration of sensory cells (karyorrhexis, karyopyknosis, and necroptosis; $\mathrm{Hu}$ et al., 2000); 3) increased numbers of synaptic vesicles in medial efferent nerve endings and swelling of the afferent nerve endings on the inner hair cells (IHCs) with incipient retrograde nerve degeneration (Spoendlin, 1971); and in more severe cases, 4) complete degeneration of the organ of Corti (Bredberg et al., 1972). At the level of the tectorial membrane, morphological changes on the outer hair cell $(\mathrm{OHC})$ stereocilia imprints have also been shown (Morisaki et al., 1991) after acoustic overstimulation. These changes are coincident with a transformation from circular to oval or irregular shape, fusion of adjacent concavities to form a larger concavity, and occasionally the appearance of filamentous material. Such modification of the imprints has remained for as long as a year, after sensory hairs have disappeared.

Cetaceans include the suborder odontocetes, or toothed whales, comprising approximately 80 different species. Their adaptation to the marine environment has led to the evolution of an echolocation system (Au, 1993; Thomson and Richardson, 1995; Ketten, 2000) that operates at very high frequencies $(20-180 \mathrm{kHz})$, which they use for orientation, foraging, and probably communication among members of the same social group.

Previous morphological studies on the odontocete inner ear by light microscopy can be found in the literature. A detailed description of cochlear morphology was conducted for the bottlenose dolphin Tursiops truncatus (Wever et al., 1971a-c) and the Pacific white-sided dolphin Lagenorhynchus obliquidens (Wever et al., 1972). Also, cochlear fibers in diverse species (Gao and Zhou, 1992), as well as features of the basilar membrane and osseous spiral lamina in different odontocete species have been compared and related to their hearing capa- bilities (Ketten and Wartzok, 1990; Ketten, 1992, 1994, 2000). However, ultrastructural descriptions of hearing structures in odontocete species using electron microscopy are still lacking, primarily due to the difficulty of obtaining suitable quality material and reliable protocols for analysis.

Detailed characterizations of the organ of Corti in echolocating horseshoe bats (Rhinolophus rouxi) using scanning (SEM) and transmission (TEM) electron microscopy have been published (Vater and Lenoir, 1992; Vater et al., 1992; Vater and Kössl, 2011). Special features of the very high frequency hearing species were described, such as the very robust attachment between the $\mathrm{OHC}$ cuticular plates and the Deiters cells, and the very well developed cup formation of the Deiters cell bodies that house the bottom of the OHC. Because of the similar functionality of the biosonar in bats, we focused on the same hearing structures in odontocetes to investigate possible morphological similarities among these echolocating species, using both SEM and TEM.

The objectives of this study were 1) to describe structural features of the organ of Corti in several odontocete species that can be further correlated with their respective hearing sensitivities; and 2) to conduct a morphological analysis of the cochlea to investigate possible structural alterations as a consequence of sound exposure.

\section{MATERIALS AND METHODS}

\section{Extraction and fixation}

A total of 150 ears from 13 odontocete species (Phocoena phocoena, $n=71$; Stenella coeruleoalba, $n=30$; Stenella frontalis, $n=12$; Tursiops truncatus $n=9$; Delphinus delphis, $n=11$; Kogia simus, $n=2$; Kogia breviceps, $n=3$; Globicephala macrorhynchus, $n=1$; Globicephala melas, $n=3$; Steno bredanensis; $n=2$; Lagenodelphis hosei, $n=1$; Hyperoodon ampullatus, $n=2$; and Ziphius cavirostris, $n=2$ ) that stranded in the Mediterranean Sea, Spanish North Atlantic, and North Sea were extracted following the protocol presented at the European Cetacean Society Conference in Istanbul (Morell and André, 2009), and adopted at the Necropsy Workshop, Liège, 2009 (see Table 1 for more details).

After extraction, the samples were fixed with $10 \%$ buffered formalin or $2.5 \%$ glutaraldehyde in $0.1 \mathrm{M}$ phosphate buffer ( $\mathrm{pH}$ 7.3-7.4). Thirty-six were perfused through the oval and round window replacing the perilymph with the fixative solution.

\section{Decalcification}

Because cetacean cochleas are surrounded by very dense periotic bone, it is necessary to decalcify the 
TABLE 1.

Total Number of Samples by Species, Decalcification Agent, and Type of Analysis Performed

\begin{tabular}{|c|c|c|c|c|c|c|c|}
\hline Species & Common name & No. & $\mathrm{RDO}^{\circledR}$ & EDTA & $\mathrm{EDTA}+\mathrm{Mw}$ & SEM & TEM \\
\hline Phocoena phocoena & Harbor porpoise & 71 & 57 & 9 & 5 & 18 & 4 \\
\hline Stenella coeruleoalba & Striped dolphin & 30 & 23 & 6 & 1 & 25 & 1 \\
\hline Stenella frontalis & Atlantic spotted dolphin & 12 & 12 & & & 4 & \\
\hline Tursiops truncatus & Bottlenose dolphin & 9 & 9 & & & 3 & \\
\hline Delphinus delphis & Common dolphin & 11 & 7 & 2 & 2 & 7 & \\
\hline Steno bredanensis & Rough-toothed dolphin & 2 & 2 & & & & \\
\hline Kogia breviceps & Pygmy sperm whale & 3 & 3 & & & 1 & \\
\hline Kogia simus & Dwarf sperm whale & 2 & 2 & & & & 1 \\
\hline Globicephala macrorhynchus & Short-finned pilot whale & 1 & 1 & & & & \\
\hline Globicephala melas & Long-finned pilot whale & 3 & 2 & 1 & & 3 & \\
\hline Lagenodelphis hosei & Fraser's dolphin & 1 & 1 & & & 1 & \\
\hline Hyperoodon ampullatus & Northern bottlenose whale & 2 & 1 & 1 & & 1 & \\
\hline Ziphius cavirostris & Cuvier's beaked whale & 2 & 2 & & & 1 & \\
\hline Total & & 150 & 123 & 19 & 8 & 64 & 6 \\
\hline
\end{tabular}

Abbreviations: RDO ${ }^{\circledR}$, commercial rapid decalcifier (Apex Engineering Products, Aurora, IL), EDTA, ethylenediaminetetraacetic acid; Mw, microwave oven; SEM, scanning electron microscope; TEM, transmission electron microscope.

samples to gain access to inner ear structures. Although different solutions were tested (Table 1), most samples were decalcified by using the commercial agent RDO ${ }^{\circledR}$ (Apex Engineering Products, Aurora, IL) as described in Morell et al. (2009). RDO is a rapid decalcifier based on hydrochloric acid. Depending on the tympanic-periotic complex volume (Morell et al., 2007), it can take from a few hours to a few days to decalcify the bone tissue. Better control of the decalcification endpoint was obtained by using 50\% RDO (diluted in distilled water) and changing to 25\% RDO after 24 hours (Morell et al., 2009). Other samples were decalcified by using $14 \%$ ethylenediaminetetraacetic acid (EDTA) tetrasodium salt at $\mathrm{pH} 7.4$ and 7.6 either at room temperature (changing the solution once per week; Callis and Sterchi, 1998) or in a microwave oven (Leica [Nussloch, Germany] AM AMW, $45^{\circ} \mathrm{C}, 30 \mathrm{~W}$, at the Regional Center for Cellular Imaging Resources (CRIC), Montpellier, France; and a Milestone [Shelton, CT] Ethos Plus, $45^{\circ} \mathrm{C}$, at the Technical Research Service of Girona University, Spain).

\section{Transmission electron microscopy}

Only the freshest samples that were perfused with 2.5\% glutaraldehyde with $0.1 \mathrm{M}$ phosphate buffer were used for morphological description by TEM. These were completely decalcified, and the endpoint was determined by using the weight loss/weight gain procedure (Mawhinney et al., 1984; Hornbeck et al., 1986; Sanderson et al., 1995) and X-ray imaging. Specifically, the TEM samples presented here were taken from: 1) an adult striped dolphin ( $S$. coeruleoalba) ear recovered in the North of Spain, fixed for 5 hours and 30 minutes postmortem and perfused with the same fixative solu- tion 9 hours postmortem 2) a juvenile harbor porpoise ( $P$. phocoena) stranded on the Belgian coast, perfused with fixative 22 hours and 10 minutes postmortem 3) an adult harbor porpoise perfused for at least 3 hours and 15 minutes postmortem 4) a neonate harbor porpoise perfused for less than 4 hours postmortem and 5) a juvenile harbor porpoise perfused for less than 12 hours postmortem (Table 1). Individuals 3, 4, and 5 were stranded on The Netherlands coast.

The samples from individuals 1-3 were postfixed for 1 hour with buffered $2 \%$ osmium tetroxide, dehydrated with increasing concentrations of ethanol, and embedded in EPON resin by using an automatic microwave tissue processor (Leica AM AMW) for electron microscopy. Semithin sections were examined under a light microscope and ultrathin sections under the Hitachi H-7100 TEM (at CRIC, Montpellier, France).

The samples from individuals 4 and 5 were postfixed with $2 \%$ osmium tetroxide, dehydrated with increasing concentrations of ethanol, and then embedded in SPURR resin using a Pelco (Ted Pella, Redding, CA) microwave. Semithin and ultrathin sections were cut, and the latter were examined by using the Hitachi H7600 TEM (University of British Columbia Bioimaging Facility, Vancouver, BC, Canada) and the FEI Tecnai G2 Spirit (Department of Cellular and Physiological Sciences, University of British Columbia).

\section{Scanning electron microscopy}

The decalcification of the periotic bone was stopped when the vestibular scalae and the stria vascularis of the cochlea were uncovered. A total of 64 cochleas and their tectorial membranes were dissected, dehydrated through ethanol, critical point dried with $\mathrm{CO}_{2}$, 
TABLE 2

Mean Measurements (in $\mu \mathrm{m}$ ) Using Transmission Electron Microscopy and Light Microscopy of the Outer Hair Cells (OHCs), Deiters Cells, Basilar Membrane, and Spiral Ligament of Different Basoapical Locations ${ }^{1}$

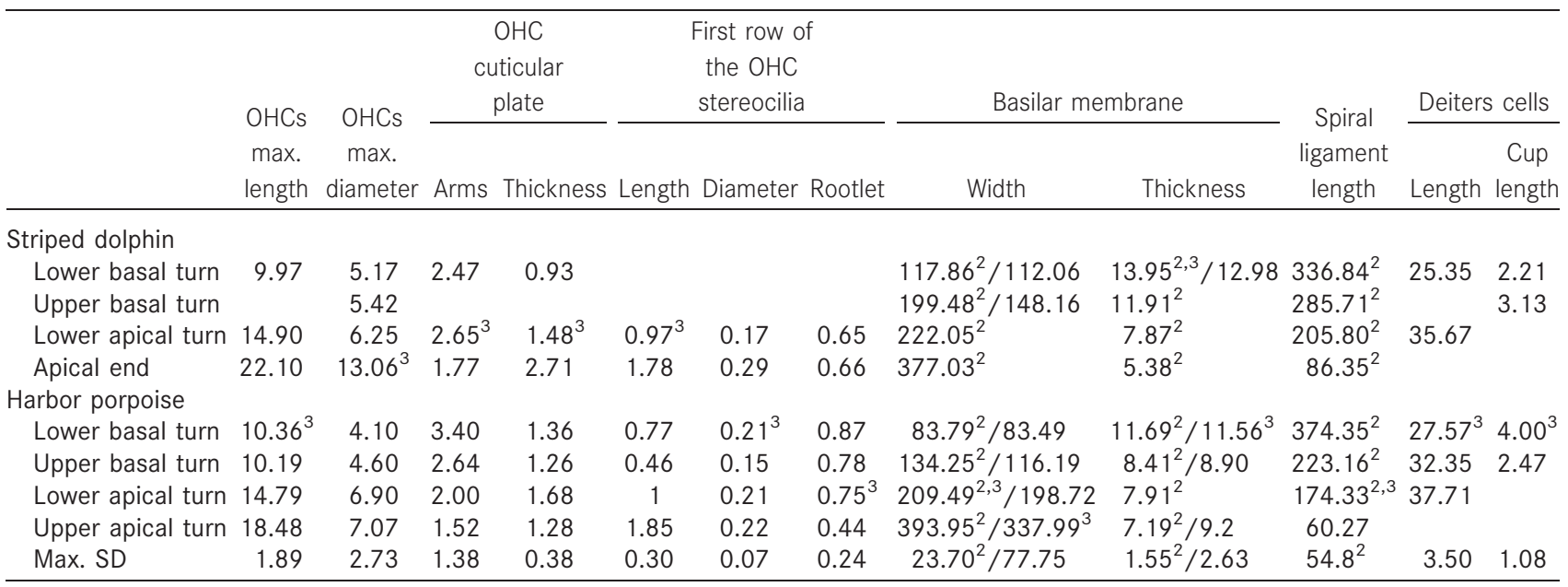

${ }^{1}$ See Figure $1 \mathrm{~A}-\mathrm{C}$ for more details on the measurements.

${ }^{2}$ Measurements performed with light microscopy.

${ }^{3}$ Measurement that presents the maximum standard deviation (max. SD).

and then coated with gold-palladium (Table 1). The samples were observed by SEM for morphological description and for possible acoustic trauma assessment. Imaging was done on a Hitachi S-3500N (at the Institute of Marine Sciences, Spanish National Research Council, Barcelona, Spain), a Hitachi S-4000 (at CRIC, Montpellier, France), a Jeol JSM 5600 (at the Technological Center of Vilanova i la Geltrú, Spain), a Hitachi S-570 (at the Autonomous University of Barcelona, Spain), and a Hitachi S-4700 (University of British Columbia Bioimaging Facility).

\section{Image processing}

Brightness and contrast of images were adjusted in Adobe (San Jose, CA) Photoshop CS3. Several dimensions in the cochlear structures were measured (see

F1 Fig. 1 for details), either by using specific tools in the electron microscope software or in Image ${ }^{\circledR}$.

\section{RESULTS}

This section presents the TEM and SEM analysis of the general morphology of the organ of Corti. This structure was typically formed by one row of IHCs and three rows of OHCs. In a harbor porpoise, some additional $\mathrm{OHCs}$ were observed forming a fourth row in the lower apical turn.

\section{Transmission electron microscopy}

The average cochlear dimensions based on TEM and T2 light microscopy analysis are presented in Tables 2 and

T3 F2 3. Figure 2 shows reconstructions of the spiral course of the basilar membrane performed with Adobe Illustra- tor from SEM pictures, and indicates the positions that were analyzed by TEM. The most interesting features of each structure are presented below.

\section{Basilar membrane}

The basilar membrane (Fig. 1A,B) increased in width (i.e., the distance between the foramen of the habenula perforata and the spiral ligament) and decreased in thickness toward the apex, being especially narrow and thick in the lower basal turn. In striped dolphin, the basilar membrane ranged from an average of 112 to $377 \mu \mathrm{m}$ in width and 14 to $5 \mu \mathrm{m}$ in thickness, while in harbor porpoise the average values ranged from about 83 to $394 \mu \mathrm{m}$ in width and 12 to $7 \mu \mathrm{m}$ in thickness (Table 2). Contrary to this general trend, in the harbor porpoise the basilar membrane width ranged from 412 $\mu \mathrm{m}$ in the apex to $53 \mu \mathrm{m}$ at approximately $3 \mathrm{~mm}$ from the base, but increased again to $118 \mu \mathrm{m}$ the first $2 \mathrm{~mm}$. There was no information about the most basal region of the cochlea in the striped dolphin (Fig. 2B).

\section{Spiral ligament}

The spiral ligament was large in the lower basal turn (maximum of $359 \mu \mathrm{m}$ in striped dolphin and $488 \mu \mathrm{m}$ in harbor porpoise; Fig. 1A). Interestingly, it persisted up to the apical turn in both species.

\section{Sensory cells: outer hair cells.}

The ultrastructure of the OHCs is illustrated in Figure 3. Measurements of cell body length in over $60 \mathrm{OHCs}$ showed that OHCs of the lower basal turn (Fig. 3A) were very small (striped dolphin: $9.96 \mu \mathrm{m}$; harbor 


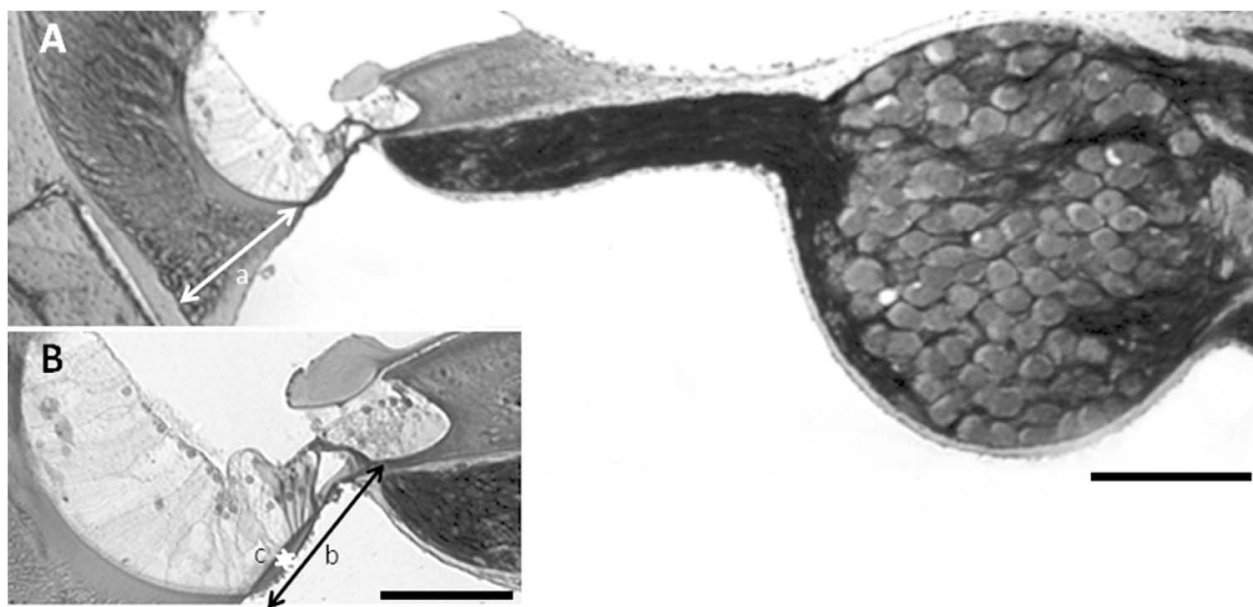

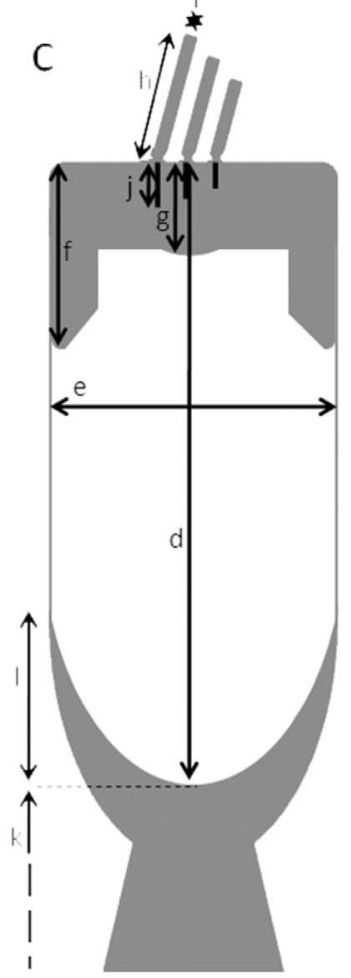

a) Spiral ligament length

b) Basilar membrane width

c) Basilar membrane thickness

d) $\mathrm{OHC}$ maximum length

e) $\mathrm{OHC}$ maximum diameter

f) $\mathrm{OHC}$ cuticular plate arms

g) $\mathrm{OHC}$ cuticular plate thickness

h) Stereocilia length

i) Stereocilia diameter
D

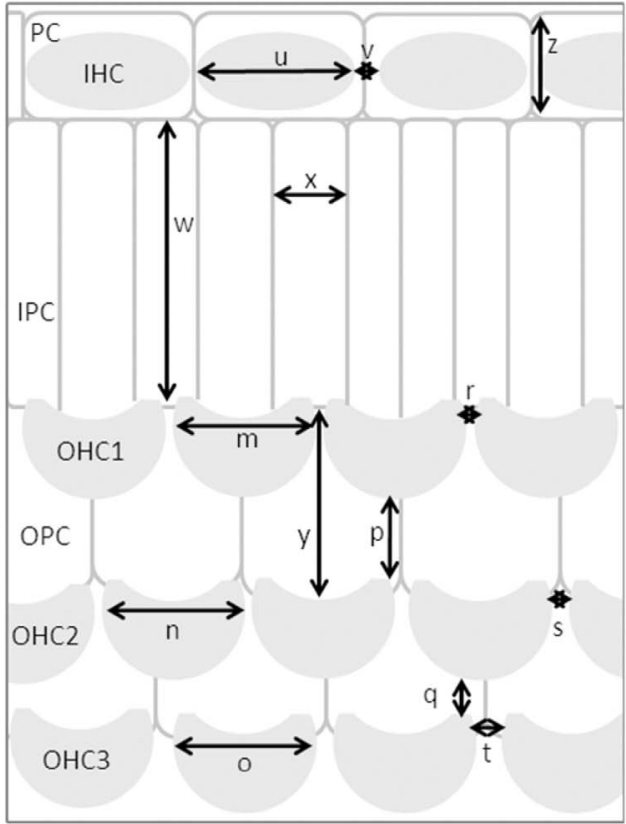

j) Stereocilia rootlet

k) Deiters cell length

s) Distance $\mathrm{OHC2}-\mathrm{OHC2}$

l) Deiters cell cup length

t) Distance $\mathrm{OHC} 3-\mathrm{OHC} 3$

m) $\mathrm{OHC} 1$ maximum length

u) $\mathrm{IHC}$ maximum length

n) $\mathrm{OHC} 2$ maximum length

v) Distance between $\mathrm{IHC}$

o) $\mathrm{OHC} 3$ maximum length bundles

p) Distance $\mathrm{OHC} 1-\mathrm{OHC} 2$

w) IPC maximum length

q) Distance $\mathrm{OHC2}-\mathrm{OHC3}$

x) IPC minimum length

r) Distance $\mathrm{OHC} 1-\mathrm{OHC} 1$

y) Deiters1 maximum length

z) PC maximum length

Figure 1. Scheme of the cochlear measurements performed using light microscopy (A,B), transmission electron microscopy (C), and scan-

T4 ning electron microscopy (D). These measurements are detailed in Table 2 (a-I) and Table 4 ( $n-z)$. A,B: Transverse section of the upper basal turn of the cochlea of a harbor porpoise stained with osmium tetroxide. C: Schematic representation of an $\mathrm{OHC}$ at the base of the cochlea and the apical part of the Deiters cell body. D: Schematic representation of the reticular lamina of the organ of Corti epithelium. IHC, inner hair cell; OHC, outer hair cell; IPC, inner pillar cell; OPC, outer pillar cell; PC, phalangeal cell. Scale bars: A) $200 \mu \mathrm{m}$, B) 100 $\mu \mathrm{m}$. 


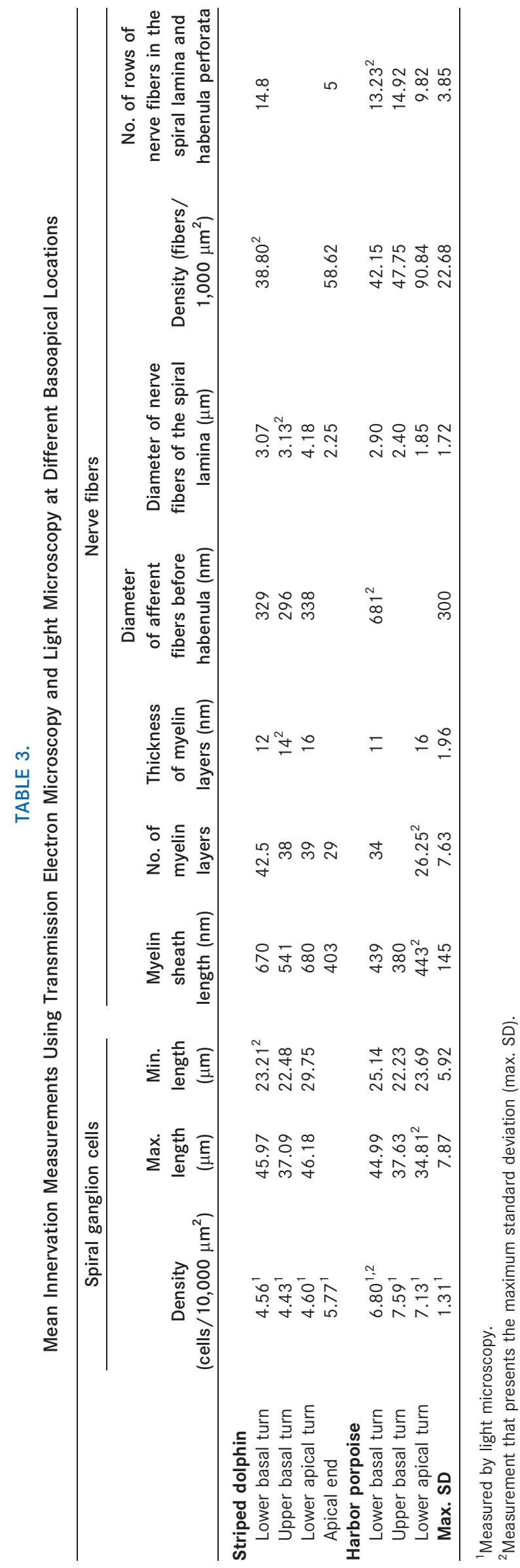

porpoise: $10.36 \mu \mathrm{m}$, with extreme values of $7.8 \mu \mathrm{m}$ ). They reached a maximal length of $22.1 \mu \mathrm{m}$ in the apical turn of the striped dolphin and 18.47 in the upper apical turn of the harbor porpoise. The $\mathrm{OHCs}$ were also very narrow, increasing in diameter while approaching the apex of the cochlea (from 5.2 to $13.1 \mu \mathrm{m}$ in striped dolphin and from 4 to $7.1 \mu \mathrm{m}$ in the lower apical turn in harbor porpoise).

\section{Stereocilia and cuticular plates}

Stereocilia were not very well preserved, and only partial data could be extracted. They were generally of very short length, being longer in the apical cochlear end (1.8 $\mu \mathrm{m}$ in striped dolphin and harbor porpoise) than in the lower basal turn $(0.8 \mu \mathrm{m}$ in harbor porpoise). $\mathrm{OHCs}$ had three rows of stereocilia. Cuticular plates of OHCs established tight junctions with the outer pillar cells and phalangeal processes of the three rows of Deiters cells. These attachment zones were extremely long in the $\mathrm{OHCs}$ of the basal turn, forming two "arms" (asterisks in Fig. 3A,C).

\section{Subsurface cisternae}

OHCs presented a single layer of subsurface cisternae (white arrows in Fig. 3F), which started just below the cuticular plate and continued down to the beginning of the synaptic region, below the nucleus.

\section{Sensory cells: inner hair cells}

IHCs were very poorly preserved, and were only observed in the lower apical turn in the striped dolphin and in the lower basal turn in the harbor porpoise.

They presented the typical pear shape (Fig. 3E) with a cuticular plate thickness of $1.57 \mu \mathrm{m}$. The tallest stereocilia of these cells were $2.97 \mu \mathrm{m}$ in length and $308 \mathrm{~nm}$ in diameter.

\section{Supporting cells}

Pillar and Deiters cells, especially at the base of the cochlea, presented an extremely well-developed microtubular cytoskeleton (Fig. 3A,G,H). The phalangeal process of Deiters cells and outer pillar cells had exaggerated long contact zones with the OHCs. This feature was especially evident on the basal turn of odontocete cochlea (asterisks in Fig. 3A,C).

The lower parts of the $\mathrm{OHC}$ bodies were completely surrounded by a large cup formed by the Deiters cells. The ultrastructure of the Deiters cup attachment is shown for the lower basal turn in harbor porpoises (black arrows in Fig. 3A). This feature was not observed in apical locations as is the case in other mammalian species like rats (Fig. 3B, courtesy of Marc Lenoir). In 

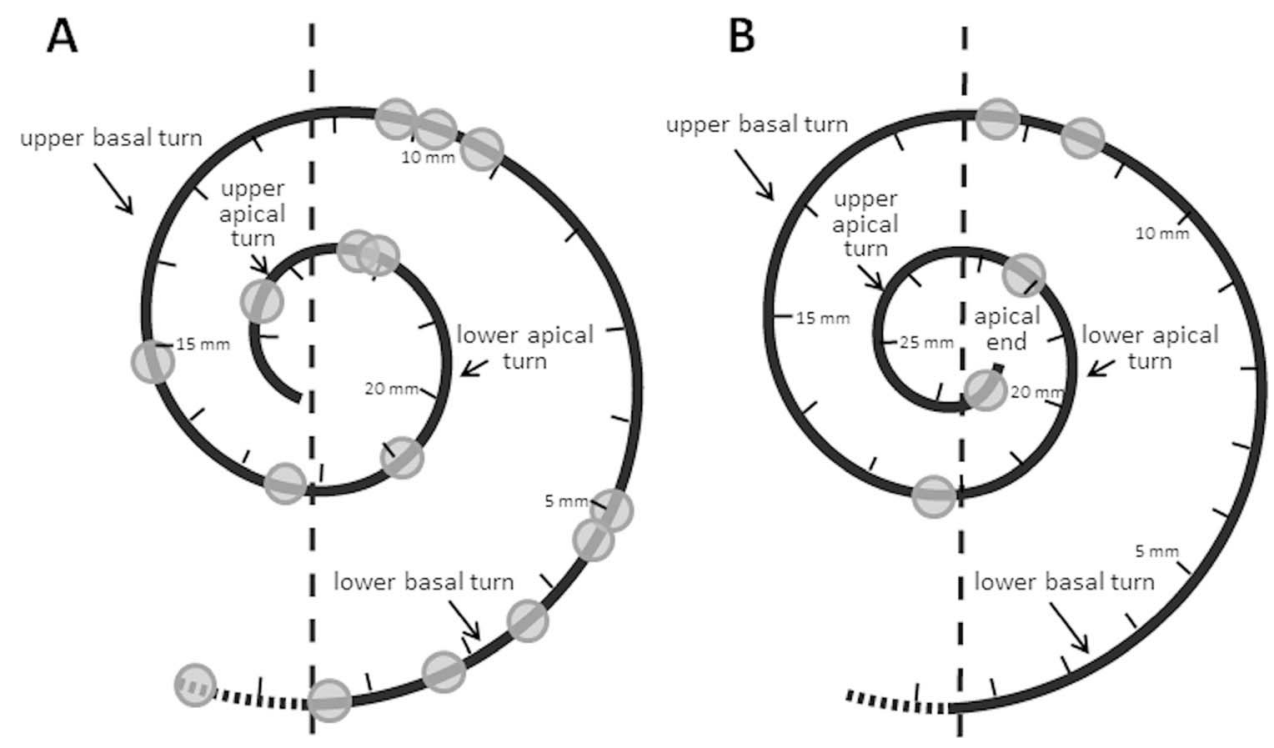

Figure 2. A,B: Schematic drawing of the cochlear shape of (A) harbor porpoise and (B) striped dolphin indicating the different regions analyzed by transmission electron microscopy. The diagram was generated with Adobe Illustrator from SEM images. Note the millimeter scale on each cochlea. Gray circles indicate where the analysis was performed.

the lower basal turn of the cochlea, this cup reached up to $45 \%$ of the total length of the OHCs.

\section{Innervation}

Along the entire cochlea of both odontocete species that we analyzed, the OHCs were contacted by nerve fibers, which passed between the Deiters cells. These fibers were clearly identified as afferent fibers by the abundant microtubule content of their cytoplasm (Fig.

F4 4C). In contrast, there were no signs of either vesiculated terminals below $\mathrm{OHCs}$ or fibers crossing the upper middle region of the tunnel of Corti, belonging to the medial efferent system, in any of the cochlear regions. Additionally, there were no remains of postsynaptic cisterns in the basal pole of the OHCs or medial efferent terminals (Fig. 4A).

The nerve fibers of the inner spiral bundle (below IHCs) showed many postmortem changes (Fig. 3E), with complete loss of nerve terminals.

Morphometric information was extracted on the nerve fibers passing in the habenula and spiral lamina, including the diameter of the fibers, the thickness of the myelin sheath, the number of myelin layers, and the number of rows of nerve fibers (Table 3 ).

The density of spiral ganglion cells (SGCs) was estimated by manually counting the SGCs from many transverse sections of different regions of the cochlear spiral of known area, using light micrographs. The SGC density was expressed as the number of cells per 10,000 $\mu \mathrm{m}^{2}$ in Rosenthal's canal. The data in Table 3 suggest an increased density toward the apex, but when all data were considered (not shown here) high variability masked any clear tendency. However, the density of SGC in harbor porpoises (from 6.8 to 8.1 SGCs/10,000 $\mu \mathrm{m}^{2}$ ) was systematically higher than in striped dolphin (from 4.4 to $5.8 \mathrm{SGCs} / 10,000 \mu \mathrm{m}^{2}$ ).

The SGCs were well preserved (Fig. 4D) and very large in size in both species. In the striped dolphin, they ranged from 37 to $46 \mu \mathrm{m}$ at their longest axis, and from 22.4 to $29.7 \mu \mathrm{m}$ at their shortest axis. By comparison, these dimensions measured 34.8-45 $\mu \mathrm{m}$ and 22.2-25 $\mu \mathrm{m}$, respectively, in the harbor porpoise.

\section{Scanning electron microscopy}

Surprisingly, the best preserved regions observed by SEM in all cochleas were the apical end, apical turn, and, in some cases, part of the upper basal turn. Consequently, we present all results from these particular locations. There were no significant differences among the measurements of the apical poles of the sensory and supporting cells within the different measured positions; thus, values in Table 4 are averaged.

\section{Sensory cells: outer hair cells}

The OHCs had narrow, wing-shaped cuticular plates that ranged in length from 5.0 to $6.2 \mu \mathrm{m}$ (Fig. 5A,B) and were separated from each other by $500-880 \mathrm{~nm}$ within a given row (Table 4). The innermost row (OHC1) and the middle row $(\mathrm{OHC} 2)$ were distinctly separated by the large hexagonal heads of the outer pillar cells. In 

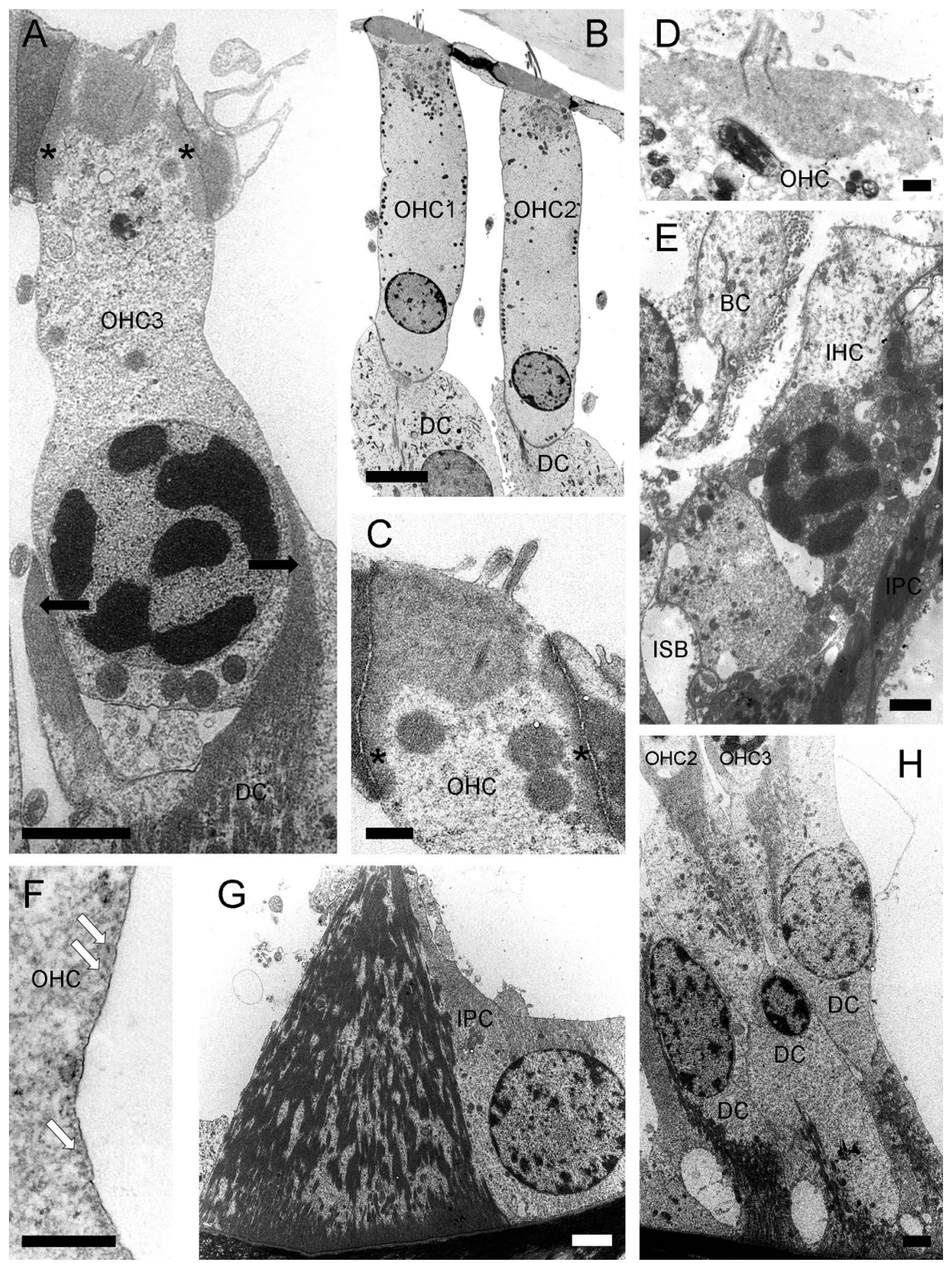

Figure 3. Ultrastructure of outer hair cells and Deiters cells of the lower basal turn of a harbor porpoise (A,C,E-H), the lower apical turn of a striped dolphin (D), and the apical turn of a rat (B; courtesy of Marc Lenoir) using TEM. Black arrows in A: Deiters cell cup attachment with the lower bodies of OHCs. Asterisks in A and C: large zone of contact between OHCs cuticular plate and supporting cells phalangeal process. Outer hair cell subsurface cisternae (white arrows in F), inner hair cell (E), and the basal body cell of the inner pillar cell (G). BC, border cell; DC, Deiters cell; IHC, inner hair cell; IPC, inner pillar cell; ISB, inner spiral bundle; OHC, outer hair cell. Scale bar $=2 \mu \mathrm{m}$ in $\mathrm{A}, \mathrm{G}, \mathrm{H} ; 5 \mu \mathrm{m}$ in $\mathrm{B} ; 500 \mathrm{~nm}$ in $\mathrm{C}-\mathrm{F}$. 

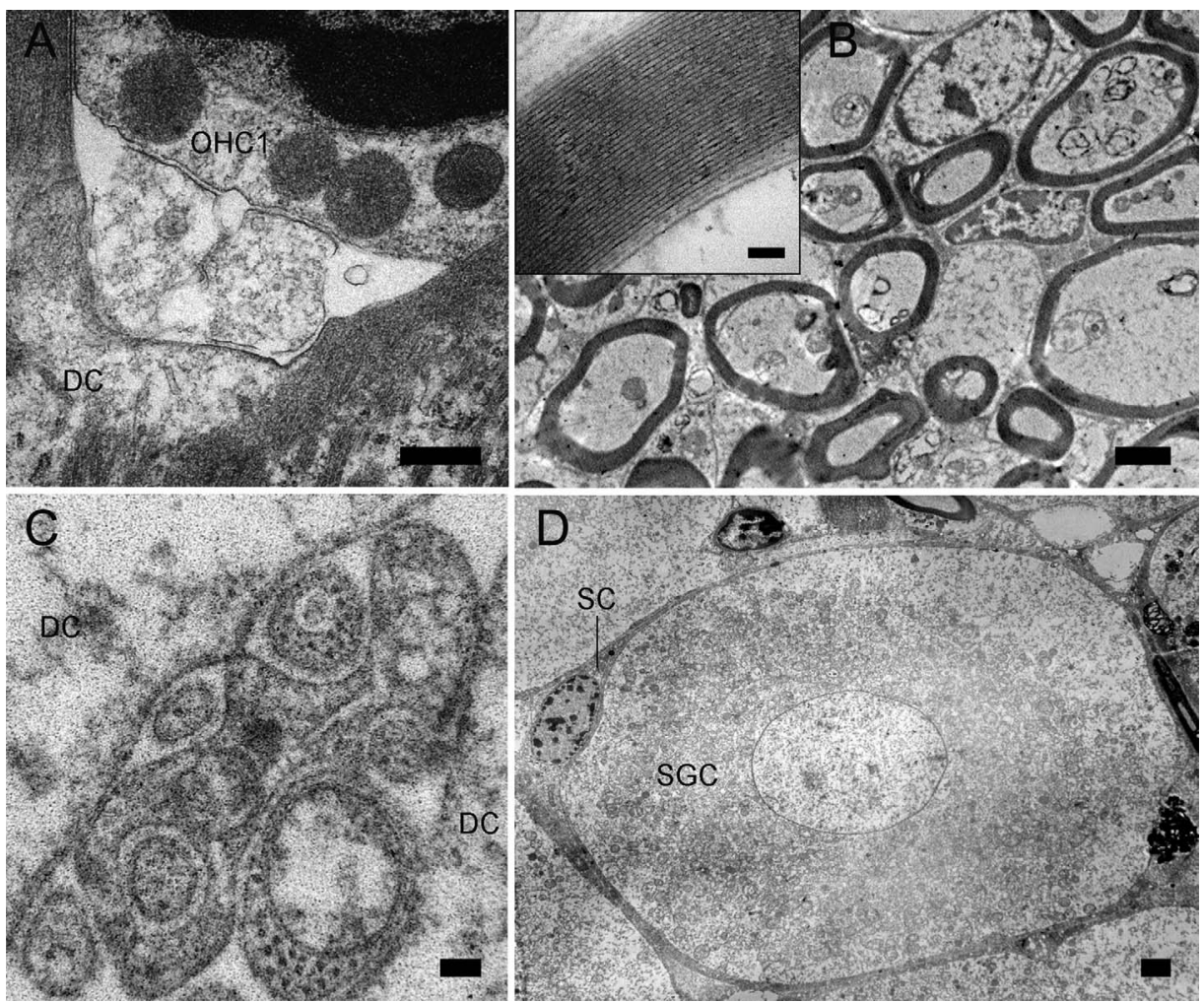

Figure 4. Transmission electron microscopic images. A: Innervation of the first row of outer hair cells (OHC 1) and cup of Deiters cells. B: Nerve fibers of the spiral lamina, including a high magnification of the myelin sheath. C: Cross section of afferent fibers containing microtubules between two Deiters cells (DC). D: Spiral ganglion cell (SGC) and satellite cell (SC). A, B, and D are from the lower basal turn of a harbor porpoise fixed for at least 3 hours 15 minutes (D), for less than 5 hours (A), for more than 22 hours (B), and for less than 12 hours (insert in B) postmortem. $C$ is from the lower apical turn of a striped dolphin, fixed 7 hours postmortem. Scale bar $=500 \mathrm{~nm}$ in $A$; $100 \mathrm{~nm}$ in zoomed area in B,C; $2 \mu \mathrm{m}$ in B,D.

contrast, there was very little space between the middle $(\mathrm{OHC} 2)$ and the outermost $(\mathrm{OHC} 3)$ rows of $\mathrm{OHCs}$, which were significantly different in both harbor porpoise $(P<0.001)$ and striped dophin $(P<0.001)$.

The OHCs appeared to have three rows of stereocilia (Fig. 5B), but more studies with better preserved samples should be conducted to confirm this result. Lateral links between stereocilia were observed in some cases (Fig. 5C). A few cells forming a fourth row of OHCs in F6 the apical region (Fig. 6B) were only found in one harbor porpoise.

The total number of OHCs was estimated taking into account their average density $\left(175.37 \mathrm{OHCs} \mathrm{m^{-1 }}\right.$ of cochlea for striped dolphin and $147.67 \mathrm{OHCs} \mathrm{mm}^{-1}$ for harbor porpoise), and extrapolating it to all averaged cochlear lengths $(26.878 \mathrm{~mm}$ for striped dolphin and $24.813 \mathrm{~mm}$ for harbor porpoise). This resulted in a total of 15,012 and 11,405 OHCs, respectively.

The cochlear length was calculated from flat SEM images, performed along the limit of the first row of $\mathrm{OHCs}$ with the inner pillar cells. The cochlear length measurements of juvenile individuals were not taken into account for this study.

Even though the samples were not well preserved, it was possible to determine the shape of $\mathrm{OHC}$ cuticular plates. It was also possible to determine whether scars were present resulting from the growth of supporting cells after the death of OHCs (Fig. 5D; see a schematic of the scar formation process in Fig. 5F). Moreover, in the case of one of the harbor porpoises, around 420 $\mu \mathrm{m}$ of the apical portion of the cochlea was full of scars (Fig. 5E).

\section{Sensory cells: inner hair cells}

The IHCs were rarely well preserved in any of the samples analyzed. The IHC cuticular plates were of oval shape (Fig. 6A). The average maximum length in striped dolphin IHC was $8.4 \mu \mathrm{m}$, and $4.5 \mu \mathrm{m}$ was the minimum average length. In the harbor porpoise, the lengths were 8.2 and $5.2 \mu \mathrm{m}$, respectively, and the IHCs were found to be separated by $1.15 \mu \mathrm{m}$; this latter distance 
was observed to be larger than the separation distance of OHCs in the same row.

The total number of IHCs was estimated following the same procedure as explained for the OHCs, resulting in a total of $3,127 \mathrm{IHCs}$ in harbor porpoise.

\section{Tectorial membrane}

Despite the poor preservation of the organ of Corti, the tectorial membrane was relatively well preserved. Figure 7 shows the imprints of stereocilia that were found in the tectorial membrane of different species. Even in a sample of one of the bottlenose whales (Hyperoodon ampullatus) where there were no remains of the organ of Corti present in the sample, the imprints of the $\mathrm{OHC}$ stereocilia were observable in the tectorial membrane (Fig. 7C). By counting the number of imprints, it was possible to estimate the number of the longer stereocilia per $\mathrm{OHC}$, and, assuming that each $\mathrm{OHC}$ contained three rows of stereocilia (Fig. 5B), it was possible to estimate the total number of stereocilia. This estimate ranged from 130 to 168 , depending on the species (Table 5).

Impressions of the IHC stereocilia were detected in the very basal partition of the tectorial membrane (arrows in Fig. 7G,H) in one of the common dolphins.

\section{DISCUSSION}

Rapid postmortem decomposition of the organ of Corti combined with the difficulty of obtaining very "fresh" cochleas made our analysis challenging. In addition, decalcification artifacts could make data interpretation difficult. Despite these potential problems, we were able to describe, for the first time, the general ultrastructure of the odontocete cochlea using electron microscopy. This section will discuss our findings at each structural level of the organ of Corti, based on SEM and TEM observations and in the context of other echolocating species of mammals.

\section{Sensory cells}

In general, the pear-shaped form of IHCs and the cylindrical shape of $\mathrm{OHCs}$ in odontocete cochlea resemble the typical forms of these receptor cells in other mammals (see Lim, 1986 for review), although differences in dimensions of the $\mathrm{OHCs}$ deserve further comment. Typically, $\mathrm{OHCs}$ in terrestrial mammals are between 20 and $70 \mu \mathrm{m}$ (Pujol et al., 1997). However, the $\mathrm{OHCs}$ of echolocating bats are somewhat smaller: $12-15 \mu \mathrm{m}$ at the base to $28-30 \mu \mathrm{m}$ at the apex in the horseshoe bat, a high-frequency hearing specialist (Vater et al., 1992), and 8-15 $\mu \mathrm{m}$ in bicolored roundleaf bats (Hipposideros bicolor; Dannhof and Bruns, 

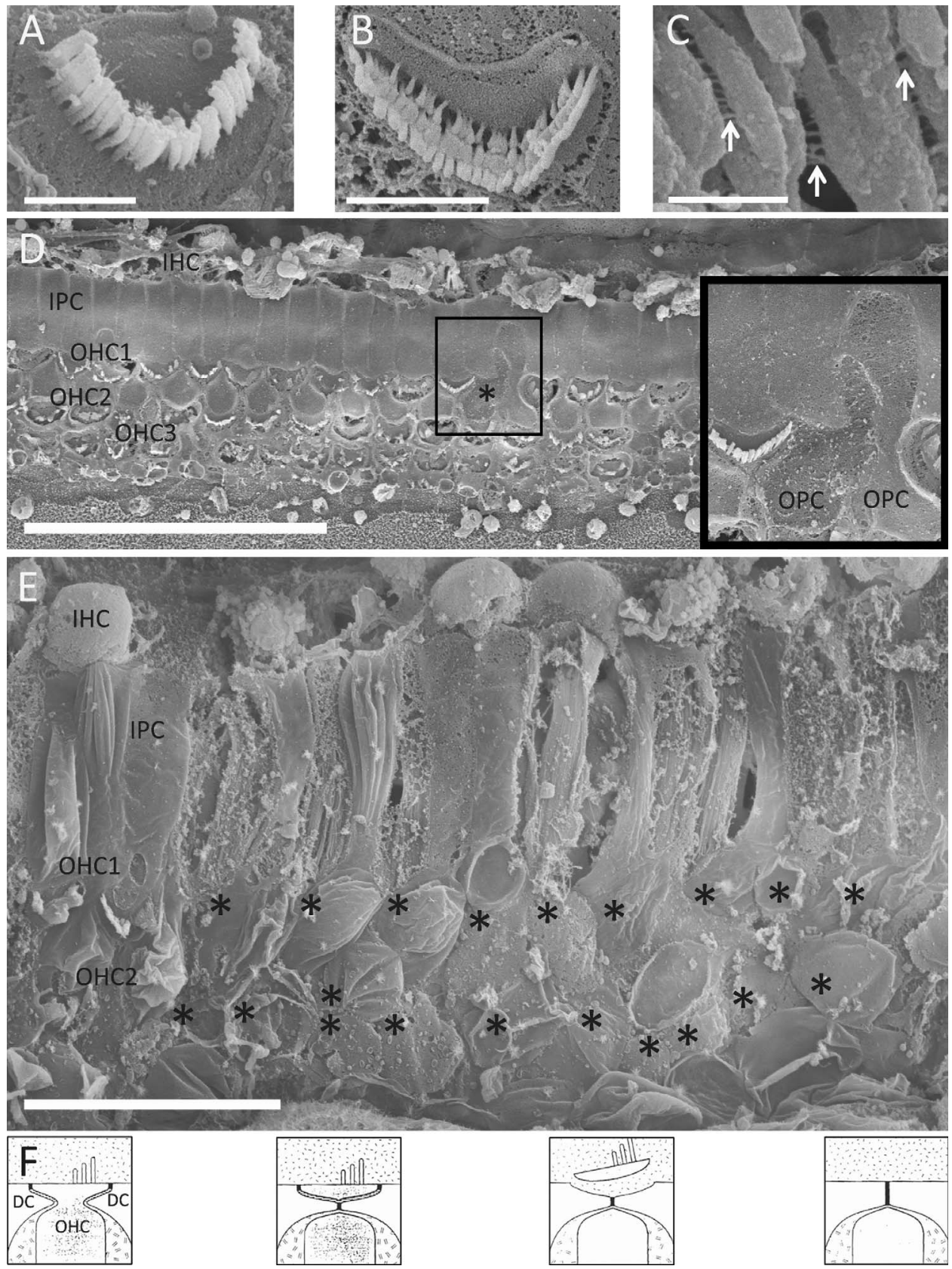

Figure 5. Scanning electron microscopic images of the apical pole of outer hair cells (OHCs) from the apical turn of harbor porpoises (A,C-E) and a common dolphin (B), where it is possible to observe three rows of stereocilia. C: Detail of the lateral links (arrows) attaching the outer hair cell stereocilia. D: The rectangle highlights the presence of one scar (asterisk) formed with two expansions of outer pillar cells after the disappearance of one OHC in the first row. E: All OHCs have disappeared and a large scar is formed by many supporting cells including outer pillar cells and Deiters cells. F: Schematic diagram showing the process of a scar formation (source: Leonova and Raphael, 1997, with permission of the editor). Sample B was fixed by SOCPVS before 18 hours postmortem A, D, and E were fixed by the University of Utrecht, at 16 hours (A and E), at less than 7 hours (C), and for at least 3 hours postmortem (D). IHC, inner hair cell; OHC, outer hair cell; IPC, inner pillar cell; OPC, outer pillar cell; DC, Deiters cell. Scale bar $=2 \mu \mathrm{m}$ in A; $3 \mu \mathrm{m}$ in B; $500 \mathrm{~nm}$ in C: $50 \mu \mathrm{m}$ in D; $20 \mu \mathrm{m}$ in $\mathrm{E}$.

1991). Light microscope measurements revealed that $\mathrm{OHC}$ length ranged from 8 to $17 \mu \mathrm{m}$ in the bottlenose dolphin (Wever et al., 1971a), from 10 to $22 \mu \mathrm{m}$ in the striped dolphin, and from 8 to $18.5 \mu \mathrm{m}$ in the harbor porpoise (present study).
A linear relationship exists between frequency and OHC length in terrestrial mammals (Pujol et al., 1991; Dannhof et al., 1991). Indeed, the length of the OHCs increases while the apex is approached. Because the absolute length of OHCs may play a role in an intrinsic 

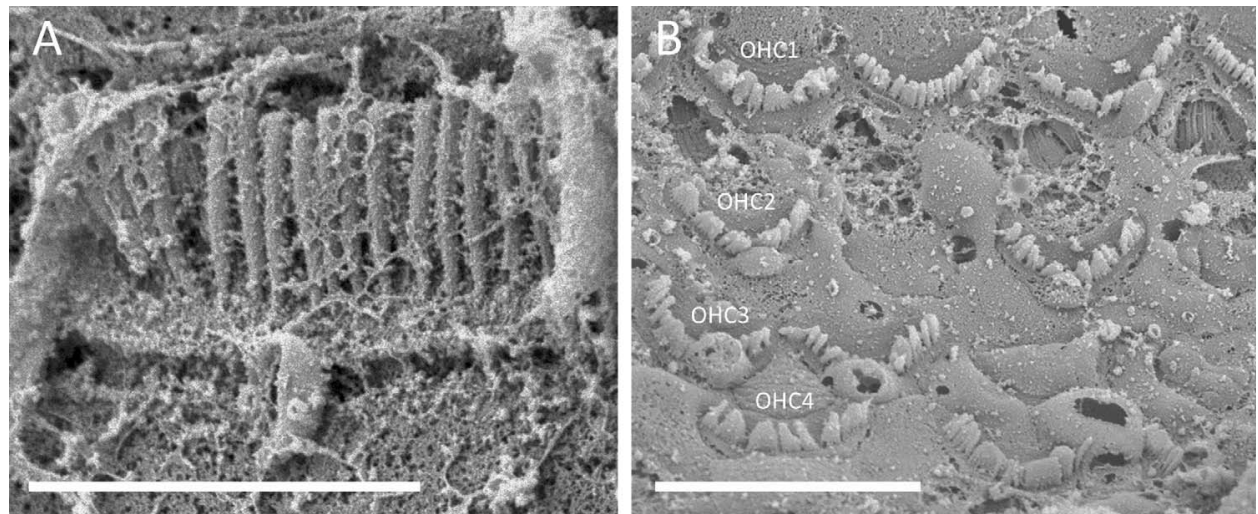

Figure 6. Scanning electron microscopy images. A: An inner hair cell stereociliary bundle in the upper basal turn of a striped dolphin cochlea perfused 7 hours postmortem. B: A few cells forming a fourth row of outer hair cells in the apical turn of a harbor porpoise cochlea fixed 9 hours postmortem. The samples were provided by AMBAR (A) and University of Liège (B). OHC, outer hair cell. Scale bar $=5 \mu \mathrm{m}$ in $\mathrm{A} ; 10 \mu \mathrm{m}$ in $\mathrm{B}$.

tuning mechanism (Pujol et al., 1991), the small size of odontocete $\mathrm{OHCs}$ is consistent with a morphological adaptation to high-frequency hearing. These results confirm that odontocetes, together with bicolored roundleaf bats, present the shortest $\mathrm{OHC}$ ever described in mammals and reflect the higher frequency hearing capabilities of these animals. Harbor porpoises, for example, can hear up to $180 \mathrm{kHz}$ (Kastelein et al., 2002) and roundleaf bats up to $200 \mathrm{kHz}$ (Neuweiler et al., 1984), whereas most echolocating bats hear up to $150 \mathrm{kHz}$ (Grinnell, 1995). Interestingly, a comparison of $\mathrm{OHC}$ length in the odontocetes we studied and the codified frequency of these particular cells in other species shows that these odontocetes do not follow the relationship described by Pujol et al. (1991) and Dannhof et al. (1991); in fact, we found that OHCs were much shorter than expected all along the cochlear spiral. The reason for this discrepancy is not yet clear.

In addition to their short length, the $\mathrm{OHCs}$ also had relatively small diameters. Unlike terrestrial mammals, in which $\mathrm{OHC}$ diameter is approximately constant at 7 $\mu \mathrm{m}$, in the species in this study $\mathrm{OHC}$ diameter ranged from 3.9 to $5.4 \mu \mathrm{m}$. The smaller $\mathrm{OHC}$ dimensions in these odontocetes might coincide with a decrease in the $\mathrm{OHC}$ lateral membrane surface and a decrease in the membrane cell capacitance, thus increasing conductance and sensitivity to high frequency (Housley and Ashmore, 1992). The total numbers of IHCs $(2,842)$ and OHCs $(10,367)$, estimated here for harbor porpoise, and OHCs $(13,405)$ for striped dolphin were consistent with previous results for other odontocete species. For example, 3,272 IHCs and 12,899 OHCs were calculated for the Pacific white-sided dolphin (Wever et al., 1972), and 3,451 IHCs and 13,933 OHCs for the bottlenose dolphin (Wever et al., 1971a). The magnitude of these hair cell estimations is similar to what was reported by Retzius (1884) for the human ear $(3,475$ IHCs and 11,500 OHCs), which has about the same cochlear length.

\section{Stereocilia}

The number of stereocilia on the outermost row per $\mathrm{OHC}$ was high and seemed to be constant along the cochlear length. If the cells have the same number of stereocilia in all rows, the number on each cell would range from 130 in harbor porpoise to 168 in striped dolphin (Table 5), but further research is needed to confirm these results. In some terrestrial mammals the number of stereocilia changes along the basoapical axis and between the $\mathrm{OHC}$ rows. For example, in humans the number of $\mathrm{OHC}$ stereocilia varies from 50 to 120 between the apical and basal turns (Kimura et al., 1964); in chinchillas the number of $\mathrm{OHC} 1$ and $\mathrm{OHC} 2$ stereocilia remains quite constant (100-110 stereocilia in the basal turn and 90-100 in the apex), whereas in the $\mathrm{OHC} 3$ the number of stereocilia varies from 80 in the basal turn to 18-40 in the apical turn (Lim, 1986). The large number of stereocilia in cetaceans may have at least two consequences: 1) to improve the functional relationship between the tectorial membrane and the organ of Corti; 2) to increase the number of ion channels that would facilitate depolarization of the cell and enhance its sensitivity (Assad et al., 1991).

\section{Scarring process}

In the case of a harbor porpoise in which we observed extensive scar formation in the $\mathrm{OHC}$ region of a large portion of the upper apical turn (Fig. 5E), scarring damage would affect the hearing in the lower frequency range. Once the cochlear frequency map for a species 

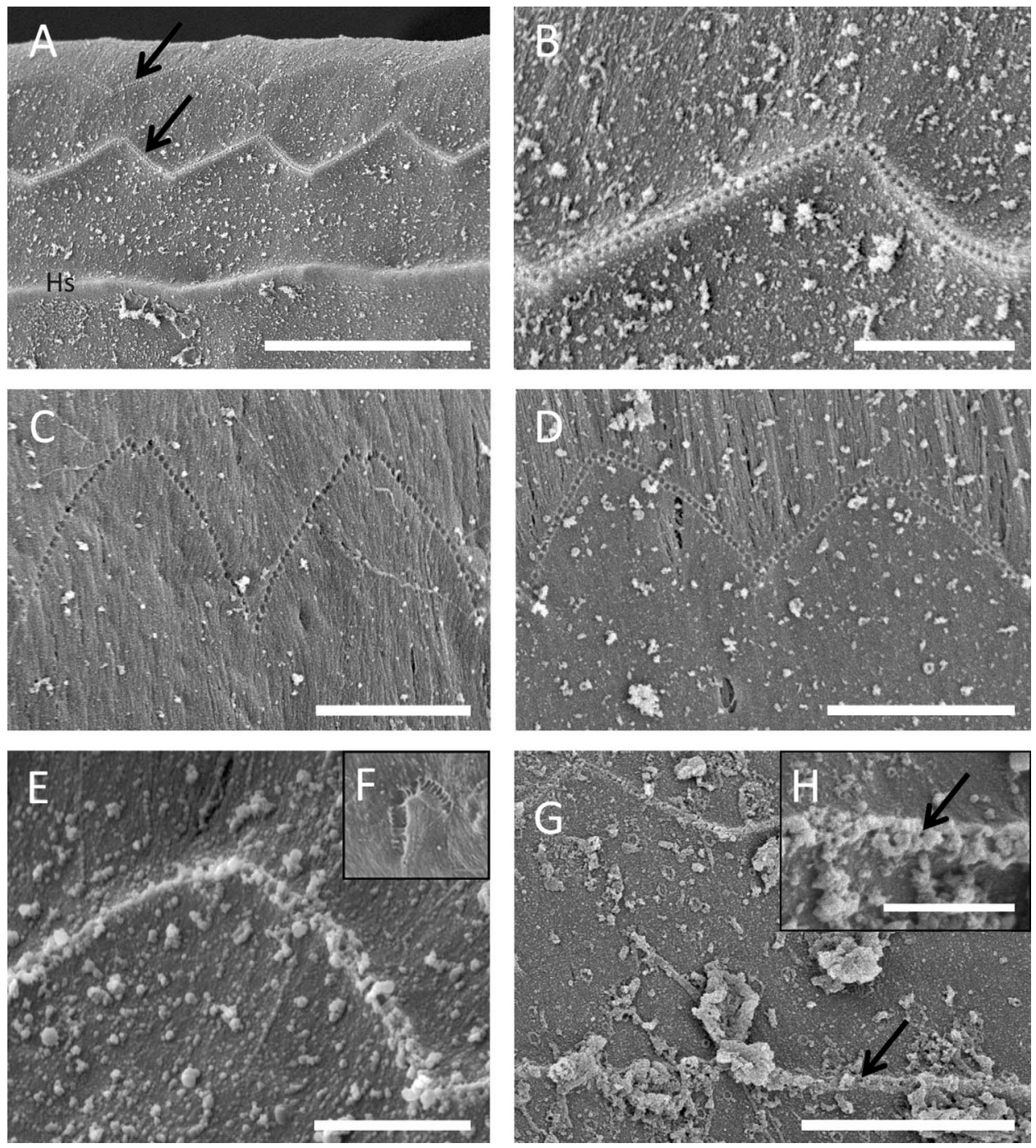

Figure 7. Scanning electron microscopy images of the outer hair cell stereocilia imprints on the undersurface of the tectorial membrane of a striped dolphin (A, arrows, and B), northern bottlenose whale (C), harbor porpoise (D), and common dolphin (E). F: Enlarged imprints in the tectorial membrane of a guinea pig cochlea after a loud sound exposure (reproduced from Morisaki et al., 1991, with permission of the editor). G,H: Inner hair cell stereocilia imprints (arrows) on the Hensen stripe of the most basal portion of the tectorial membrane of a common dolphin. The samples were provided by the Generalitat de Catalunya-Fundació CRAM $(A, B)$, the University of La Rochelle (C), the University of Liège (D), and SOCPVS (E,G,H). Hs, Hensen stripe. Scale bar $=10 \mu \mathrm{m}$ in $A ; 3 \mu \mathrm{m}$ in $B, C ; 5 \mu \mathrm{m}$ in $D, G ; 2 \mu \mathrm{m}$ in $\mathrm{H} ; 1.5 \mu \mathrm{m}$ in E.

TABLE 5.

Analysis of the Outer Hair Cell $(\mathrm{OHC})$ Stereocilia Imprints on the Undersurface of the Tectorial Membrane

\begin{tabular}{lcccc}
\hline Tectorial membrane & No. of imprints & No. of stereocilia/OHC & No. of animals & No. of cells \\
\hline Striped dolphin & 56 & 168 & 2 & 6 \\
Harbor porpoise & 43.4 & 130.2 & 3 & 1 \\
Northern bottlenose whale & 49.6 & 148.8 & 158 & 15 \\
Common dolphin & 52.75 & 158.25 & 2 & 8 \\
\hline
\end{tabular}

is resolved, it will be possible to estimate the acoustic characteristics of a source that may have caused damage by acoustic overstimulation. This is possible because "the greatest hearing-loss occurs at a fre- quency about half an octave above the exposure tone" (Davis et al., 1950). The frequency range of the suspect source could correspond to several anthropogenic marine activities, for example, shipping, pile driving, or 
seismic operations. However, other causes cannot be ruled out. For example, this particular animal was relatively old, and studies of age-related hearing loss in other mammals have shown that the base of the cochlea is consistently affected, as well as, in some cases, a small region of the apex (Johnsson and Hawkins, 1972; Spongr et al., 1997). Nevertheless, although the basal turn of the cochlea was not well preserved, thus preventing determination of the possible influence of aging in the analysis, we could clearly distinguish between disappearance of hair cells prior to death and damage to hair cells due to autolysis. In the first case, the stereociliary bundle was missing and a scar was made by neighboring epithelial cells. In the second case, the stereocilia were generally missing, but the cuticular plate of the hair cells remained and the epithelial mosaic was retained.

\section{Subsurface cisternae}

In the horseshoe bat (Vater et al., 1992), Mexican freetailed bat (Vater and Siefer, 1995), rats, mice, and human (Arnold and Anniko, 1990) there is only one layer of subsurface cisternae. In contrast, guinea pig OHCs display multiple layers of subsurface cisternae, especially in the apical region (Saito, 1983). Subsurface cisternae are believed to play an important role in $\mathrm{OHC}$ motility by releasing $\mathrm{Ca}^{2+}$ (Schulte, 1993; Tolomeo et al., 1996; Oghalai et al., 1998; Koyama et al., 1999). The present study showed that the harbor porpoise and the striped dolphin present the same pattern as the horseshoe bat (Vater et al., 1992).

\section{Deiters and Pillar cells}

In the basal turn of the cochlea in odontocetes as well as echolocating bats, the exaggerated thickness of the reticular lamina, made of both Deiters cell phalanges and heads of outer pillar cells, may provide an advantage for motion at high frequencies (Vater et al., 1992). The Deiters cells, Deiters cups, and pillar cells in the basal cochlear turn of the species evaluated in our study showed robust cytoskeletal structures (Fig. 3G,H), suggesting that the mechanical anchorage of the $\mathrm{OHCs}$ is reinforced and extremely stiff compared with the arrangement in the apical turn or throughout most of the cochlea of other mammals. Significantly, the disposition of Deiters cups found in odontocetes is also found in the organ of Corti of the basal turn in echolocating bats (Henson and Henson, 1979; Dannhof and Bruns, 1991; Vater et al., 1992; Vater and Siefer, 1995). This feature may therefore be relevant for high-frequency processing (Reysenbach de Haan, 1957; Wever et al., 1971c, 1972; Vater et al., 1992).

\section{Innervation Medial efferent innervations}

Nerve endings were found connecting with the base of the $\mathrm{OHCs}$ (Fig. 4A). We interpret these nerve terminals as afferents (type II), because the OHCs were lacking postsynaptic cisternae and we did not observe thick upper crossing fibers in the tunnel of Corti. Studies in humans have shown that the efferent nerve endings and postsynaptic cistern are very resistant to anoxia, and usually remain present, even when the OHCs are in a very advanced decomposition stage (Bruns and Schmieszek, 1980; Lavigne-Rebillard and Pujol, 1988, 1990). Thus, we could not find evidence that these species receive medial efferent innervation onto the OHCs.

A lack of medial efferent innervation was also shown in echolocating horseshoe bats, in bicolor and Indian roundleaf bats (Bruns and Schmieszek, 1980; Aschoff and Ostwald, 1988; Bishop and Henson, 1988; Dannhof and Bruns, 1991; Vater et al., 1992), and in the mole rat Spalax ehrenbergi (Raphael et al., 1991), a species specialized for low-frequency hearing (Bruns et al., 1988). This evidence supports the notion that the medial efferent innervation of the OHCs may be a regulating system for the mid-frequencies, and may not be needed at extremely high and low frequencies (Vater et al., 1992). However, other studies on the echolocating species Mexican free tailed bats (Tadaria brasiliensis) and Parnell's mustached bats (Pteronotus parnellii) showed the presence of medial efferent innervation onto the OHCs (Bishop and Henson, 1988; Vater and Siefer, 1995). Thus, there is no straightforward functional explanation for the absence of medial efferent innervation in some echolocating species (Vater et al., 1992).

\section{Spiral ganglion cells}

The density of SGCs, as measured by the number of cells per cross-sectional area, in Rosenthal's canal (4.4-8 SGCs/10,000 $\mu^{2}$ ) in the odontocetes studied here is similar to that in guinea pigs (8 SGC/10,000 $\mu^{2}$; Jin et al., 2006), but much lower than in Mongolian gerbils (28.1 SGC/10,000 $\mu^{2}$; Fujita et al., 2007) or mice (between 36.3 in the apex and 39.6 SGC/ $10,000 \mu \mathrm{m}^{2}$ in the base; Sato et al., 2006). Considering that the bottlenose dolphin has three times, and the Pacific white-sided dolphin almost twice as many SGCs as the human (Wever et al., 1971a, 1972), we expected a higher density of SGCs in the odontocetes in our study. However, the SGCs of the harbor porpoise and striped dolphin were much larger in size (maximum 45 $\times 25 \mu \mathrm{m}$ and $46 \times 30 \mu \mathrm{m}$, respectively, Table 3) than those found in rodents (for example, 13-18 $\mu \mathrm{m}$ in rats; 
Bichler, 1984), and even larger than those in bottlenose dolphins, in which basal turn SGCs were $38.4 \times 25.2$ $\mu \mathrm{m}$ and middle turn SGCs were $34.4 \times 21.1 \mu \mathrm{m}$ (Wever et al., 1971a). In fact, odontocetes increase the number of SGCs by increasing the space occupied in Rosenthal's canal. There are some differences between species. For example, the number of SGCs in a transverse section of Rosenthal's canal ranged from 128 to 152 in the striped dolphin, and from 122 to 182 in the harbor porpoise (not illustrated here), but was only 8188 and 57-67 in gerbils (Ruttiger et al., 2007). Our results are consistent with the large ratio of SGCs to hair cells found by Wever and colleagues (1971a), suggesting "unusual capabilities in the utilization of auditory information." Considering that the peripheral process of each neuron contacts one IHC, it could be inferred that, in the cochlea of the odontocetes analyzed in this study, IHCs have many more afferent synapses than IHCs in cochleas of terrestrial mammals. In turn, this rich afferent innervation should provide functional advantages to these odontocetes, possibly increasing sensitivity and/or dynamic range.

\section{Basilar membrane}

The width and thickness of the basilar membrane have been measured in several mammalian species (Nadol, 1988; Roth and Bruns, 1992; Sato et al., 1999; Keiler and Richter, 2001). A clear gradient in width and thickness has been reported in most species as well as in the odontocetes analyzed in this study: narrower, thicker, and relatively stiff in the base, and broader and thinner in the apex.

The basilar membrane was wider and thinner in approximately the first $2 \mathrm{~mm}$ of the cochlea. A decrease in basilar membrane thickness in the basal hook was previously described in Parnell's mustached bat and the greater horseshoe bat (Bruns, 1976; Kössl and Vater, 1985), and an increase in width in bicolored roundleaf bat (Dannhof and Bruns, 1991). The functional role of the basilar membrane is not very well understood. In the case of the bottlenose dolphin, the width of the basilar membrane increased by about 14 times from the base $(25 \mu \mathrm{m})$ to the apex $(350 \mu \mathrm{m}$; Wever et al., 1971b), whereas the thickness diminished by five times (from 25 to $5 \mu \mathrm{m}$ ). However, the basilar membrane in humans showed an increase in width of only about four times (from 125 to $500 \mu \mathrm{m}$ ) and a threefold decrease in thickness from the base $(7 \mu \mathrm{m})$ to the apex (2 $\mu \mathrm{m})$ (Schuknecht, 1993; Ketten, 1998).

The values obtained for the harbor porpoise and the striped dolphin (Table 2) did not show an increasing trend, as in the bottlenose dolphin, even though the striped dolphin and the bottlenose dolphin have similar hearing sensitivities. It is possible that this difference in dimensions could result from a lack of information on the extreme locations of the cochlea (first and last millimeters; Fig. 2), or because the criterion to establish the limits of the basilar membrane was different. Further comparative research should be conducted to investigate differences between these species. In odontocetes, the basilar membrane is very stiff at the base of the cochlea, fixed to both sides by a very welldeveloped inner and outer osseus spiral laminae that confers an adaptation for very high-frequency hearing (Wever et al., 1971b; Ketten and Wartzok, 1990; Ketten, 1992, 1994).

\section{Tectorial membrane}

Despite the very fast autolysis processes after death, the tectorial membrane was less affected than other structures, perhaps because it is composed of an extracellular matrix (Slepecky et al., 1992). The high resistance of this structure to anoxia would allow the diagnosis of possible alterations in the $\mathrm{OHC}$ stereocilia due to acoustic trauma (Morisaki et al., 1991), even if the cochlea was fixed after more than 20 hours postmortem. In all our samples, the imprints of stereocilia on the tectorial membrane were regular. Because the shape of these imprints mirrors the initial organization of the stereocilia in the OHCs, there was no evidence of acoustic trauma. That is not to say that acoustic trauma did not occur in some other specimens, as suggested by the presence of epithelial scars seen in SEM (Fig. 5E). We detected the presence of IHC stereocilia impressions in the very basal region of a common dolphin tectorial membrane (Fig. 7G,H) for the first time in odontoces; this feature has been previously described in rats (Lenoir et al., 1987) and bats (Vater and Lenoir, 1992). However, Matsumura (2001) was unable to demonstrate a direct physical attachment between IHCs and the tectorial membrane in most mammalian species. We believe that this characteristic was difficult to observe in all our samples because of the degraded state of the organ of Corti.

\section{GENERAL CONCLUSIONS}

This study has, for the first time, described the ultrastructure of the organ of Corti of odontocetes. The two species of odontocetes analyzed by TEM had morphological characteristics that support high-frequency hearing, including: 1) a short length of OHCs; 2) a thick cuticular plate in $\mathrm{OHCs}$, Deiters cells, and outer pillar cells; 3) robust cup formation of the Deiters cell body; 4) a highly developed cytoskeleton in Deiters and pillar cells; and 5) a high thickness of the basilar membrane. 
All these features, in addition to a common molecular design of prestin (Li et al., 2010; Liu et al., 2010), an $\mathrm{OHC}$ motor protein (Zheng et al., 2000), and a parallel evolution of other auditory genes related to hair cell bundle motility, hair cell activity, and nerve transmission (cadherin 23, protocadherin 15, otoferlin, transmembrane cochlear-expressed gen1, and pejvakin; Davies et al., 2012; Shen et al., 2012), are also shared by echolocating bats (for review, see Vater and Kössl, 2011), suggesting a convergent evolution among echolocating species.

An additional goal of this study was to use morphological features of the inner ear to detect structural alterations that might result from sound overexposure. This proved to be difficult, because delays in tissue fixation from stranded animals resulted in cochlear decomposition that prevented us from diagnosing acoustic trauma from changes in hair cell stereocilia (Bredberg et al., 1972; Engstrom et al., 1984), or other alterations at the sensory cell (Hu et al., 2000) or innervation levels (Spoendlin, 1971). However, the presence of scars (Fig. 5D,E), which indicates premortem hair cell disappearance, could be clearly distinguished from autolysis artifacts. In fact, in one case (harbor porpoise; Fig. 5E), the lesions would be consistent with an acoustic trauma.

The tectorial membrane appeared to be more resistant to postmortem autolysis and remained in acceptable condition for analysis when the cochlea was fixed more than 20 hours postmortem. The analysis of the stereocilia imprints on the tectorial membrane has provided insights into odontocete hair cell stereocilia organization. In addition, because of the difficulties of obtaining and analyzing fresh samples of cetacean ears immediately after stranding, our results suggest an alternative approach using image analysis of the tectorial membrane, a procedure not yet common, as a diagnosis to detect possible lesions due to noise overexposure.

The results presented in this study show that the combination of the two complementary imaging techniques is necessary to document whether an odontocete has suffered from an acoustic trauma: first an overview by SEM to localize possible lesions along the cochlear axis, focusing on the presence of scars and irregularities of the imprints of the tectorial membrane; and second, a more detailed analysis by TEM to characterize the lesion on a transverse view that contains information on all the cochlear cells involved.

\section{ACKNOWLEDGMENTS}

We thank the auditory team researchers at the Institut des Neurosciences de Montpellier (INM), Jérôme Bourien,
Jing Wang, Remy Pujol, Benjamin Delprat, and Michel Eybalin, for their help and advice in interpreting the results, and Jean-Louis Pasquier for help in iconography. We are grateful for the technical assistance provided by Sabine Ladrech and Florence François (INM), Cécile Sanchez (CRIC), Lluïsa Matas and Imma Arrom (Research Technical Service of Girona University), and Derrick Horne (Bioimaging Facility, University of British Columbia). We also thank our colleagues and the stranding organizations who helped us in collecting the ears, especially Lidewij Wiersma, Lonneke IJsseldijk, and Sjoukje Hiemstra (University of Utrecht), Pablo Cermeño (AMBAR), Paco Toledano (PROMAR), Ángela Llavona, Josep M. Alonso, Alfredo López, and María Llarena (CEMMA), Beatriz González (Fundació CRAM), Encarna Gómez (University of BarceIona), Denik Ulqini (Universiteti i Shkodres), Mardik Leopold (IMARES), and Kees C.J. Camphuysen (Royal NIOZ).

\section{ROLE OF AUTHORS}

All authors had full access to all the data in the study and take responsibility for the integrity of the data and the accuracy of the data analysis. Study concept and design: Morell, André, and Lenoir. Acquisition of data: Morell, Jauniaux, Dabin, Begeman, Ferreira, Maestre, Degollada, and Hernandez-Milian. Analysis and interpretation of data: Morell, Lenoir, Puel, and André. Drafting of the manuscript: Morell, André, and Lenoir. Critical revision of the manuscript for important intellectual content: Jauniaux, Dabin, Begeman, Ferreira, Maestre, Degollada, Hernandez-Milian, Cazevieille, Fortuño, Shadwick, Vogl, and Puel. Administrative, technical, and material support: Cazevieille, Fortuño, Shadwick, Vogl and Puel. Study supervision: André, Lenoir and Shadwick.

\section{CONFLICT OF INTEREST STATEMENT}

The authors have no conflicts of interest of any nature.

\section{LITERATURE CITED}

Arnold W, Anniko M. 1990. Structurally based new functional interpretations of the subsurface cisternal network in human outer hair-cells. Acta Otolaryngol 109:213-220.

Aschoff A, Ostwald J. 1988. Distribution of cochlear efferents and olivo-collicular neurons in the brain-stem of rat and guinea-pig-a double labeling study with fluorescent tracers. Exp Brain Res 71:241-251.

Assad JA, Shepherd GMG, Corey DP. 1991. Tip-link integrity and mechanical transduction in vertebrate hair-cells. Neuron 7:985-994.

Au WWL. 1993. The sonar of dolphins. New York: SpringerVerlag.

Bichler E. 1984. Some morphological features of neurons in the rat spiral ganglion. Arch Otorhinolaryngol Arch Ohren Nasen Kehlkopfheilkd 240:243-248. 
Bishop AL, Henson OW. 1988. The efferent auditory system in doppler-shift compensating bats. In: Nachtigall PE, Moore PWB, editors. Animal sonar: processes and performance. New York: Plenum Press. p 307-311.

Bredberg G, Ades HW, Engstrom H. 1972. Scanning electronmicroscopy of normal and pathologically altered organ of Corti. Acta Otolaryngol 73:3-48.

Bruns V. 1976. Peripheral auditory tuning for fine frequencyanalysis by Cf-Fm bat, Rhinolophus ferrumequinum .1. Mechanical specializations of cochlea. J Comp Physiol 106:77-86.

Bruns V, Schmieszek E. 1980. Cochlear innervation in the greater horseshoe bat-demonstration of an acoustic fovea. Hearing Res 3:27-43.

Bruns V, Muller M, Hofer W, Heth G, Nevo E. 1988. Inner-ear structure and electrophysiological audiograms of the subterranean mole rat, Spalax ehrenbergi. Hear Res 33:110.

Callis G, Sterchi D. 1998. Decalcification of bone: literature review and practical study of various decalcifying agents, methods, and their effects on bone histology. J Histotechnol 21:49-58.

Dannhof BJ, Bruns V. 1991. The organ of Corti in the bat Hipposideros bicolor. Hearing Res 53:253-268.

Dannhof BJ, Roth B, Bruns V. 1991. Length of hair cells as a measure of frequency representation in the mammalian inner ear? Naturwissenschaften 78:570-573.

Davies KTJ, Cotton JA, Kirwan JD, Teeling EC, Rossiter SJ. 2012. Parallel signatures of sequence evolution among hearing genes in echolocating mammals: an emerging model of genetic convergence. Heredity 108:480-489.

Davis H, Morgan CT, Hawkins JE, Galambos R, Smith FW. 1950. Temporary deafness following exposure to loud tones and noise. Acta Otolaryngol Suppl 88:1-56.

Engstrom B, Borg E, Canlon B. 1984. Morphology of stereocilia on cochlear hair cells after noise exposure. In: Salvi RJ, Henderson D, Hamernik RP, editors. Basic and applied aspects of noise-induced hearing loss. New York: Plenum Press. p 1-9.

Fujita K, Hakuba N, Hata R, Morizane I, Yoshida T, Shudou M, Sakanaka M, Gyo K. 2007. Ginsenoside Rb1 protects against damage to the spiral ganglion cells after cochlear ischemia. Neurosci Lett 415:113-117.

Gao G, Zhou K. 1992. Fiber analysis of the optic and cochlear nerves of small cetaceans. In: Thomas JA, Kastelein RA, Supin AY, editors. Marine mammal sensory systems. New York: Plenum Press. p 39-52.

Grinnell AD. 1995. Hearing in bats: an overview. In: Popper AN, Fay RR, editors. Hearing in bats. New York: Springer Verlag. $p$ 1-36.

Henson MM, Henson OW. 1979. Some aspects of structural organization in the cochlea of the bat, Pteronotus parnellii. Scan Electron Microsc 3:975-982.

Hornbeck C, Emmanual J, Bloebaum RD. 1986. A comparative study of three paraffin media for preparing large decalcified bone sections. J Histotechnol 9:227-229.

Housley GD, Ashmore JF. 1992. Ionic currents of outer hair cells isolated from the guinea-pig cochlea. J Physiol 448: 73-98.

Hu BH, Guo W, Wang PY, Henderson D, Jiang SC. 2000. Intense noise-induced apoptosis in hair cells of guinea pig cochleae. Acta Otolaryngol 120:19-24.

Jepson PD, Arbelo M, Deaville R, Patterson IAP, Castro P, Baker JR, Degollada E, Ross HM, Herraez P, Pocknell AM, Rodriguez F, Howie FE, Espinosa A, Reid RJ, Jaber JR, Martin V, Cunningham AA, Fernandez A. 2003. Gasbubble lesions in stranded cetaceans-was sonar respon- sible for a spate of whale deaths after an Atlantic military exercise? Nature 425:575-576.

Jin Z, Mannstrom P, Skjonsberg A, Jarlebark L, Ulfendahl M. 2006. Auditory function and cochlear morphology in the German waltzing guinea pig. Hear Res 219:74-84.

Johnsson LG, Hawkins JE. 1972. Sensory and neural degeneration with aging, as seen in microdissections of human inner-ear. Ann Otol Rhinol Laryngol 81:179-193.

Kastelein RA, Bunskoek P, Hagedoorn M, Au WWL, de Haan D. 2002. Audiogram of a harbor porpoise (Phocoena phocoena) measured with narrow-band frequency-modulated signals. J Acoust Soc Am 112:334-344.

Keiler S, Richter CP. 2001. Cochlear dimensions obtained in hemicochleae of four different strains of mice: CBA/CaJ, 129/CD1, 129/SvEv and C57BL/6J. Hear Res 162:91104.

Ketten D. 1992. The cetacean ear: form frequency and evolution. In: Thomas JA, Kastelein RA and Supin AY, editors. Marine mammal sensory systems. New York: Plenum Press. p 56-69.

Ketten DR. 1994. Functional analyses of whale ears: adaptations for underwater hearing. IEEE Proc Underwater Acoust 1:264-270.

Ketten DR. 1998. Marine mammal auditory systems: a summary of audiometric and anatomical data and its implications for underwater acoustic impacts. La Jolla, CA: U.S. Department of Commerce, National Oceanic and Atmospheric Administration, National Marine Fisheries Service, Southwest Fisheries Science Center.

Ketten DR. 2000. Cetacean ears. In: Au WWL, Popper AN, Fay RR, editors. Hearing by whales and dolphins. Springer handbook of auditory research. New York: Springer. $p$ 43-108.

Ketten DR, Wartzok D. 1990. Three-dimensional reconstructions of the dolphin ear. In: Thomas J, Kastelein R, editors. Sensory abilities of Cetaceans. New York: Plenum Press. p 81-105.

Kimura RS, Schuknecht HF, Sando I. 1964. Fine morphology of the sensory cells in the organ of Corti of man. Acta Otolaryngol 58:390-408.

Kössl M, Vater M. 1985. The cochlear frequency map of the mustache bat, Pteronotus parnellii. J Comp Physiol A Sens Neural Behav Physiol 157:687-697.

Koyama M, Spicer S, Schulte B. 1999. Immunohistochemical localization of $\mathrm{Ca} 2+/$ calmodulin-dependent protein kinase IV in outer hair cells. J Histochem Cytochem 47: $7-12$.

Lavigne-Rebillard M, Pujol R. 1988. Hair cell innervation in the fetal human cochlea. Acta Otolaryngol 105:398-402.

Lavigne-Rebillard M, Pujol R. 1990. Auditory hair cells in human fetuses: synaptogenesis and ciliogenesis. J Electron Microsc Tech 15:115-122.

Lenoir M, Puel JL, Pujol R. 1987. Stereocilia and tectorial membrane-development in the rat cochlea-a SEM study. Anat Embryol 175:477-487.

Leonova EV, Raphael Y. 1997. Organization of cell junctions and cytoskeleton in the reticular lamina in normal and ototoxically damaged organ of Corti. Hear Res 113:1428.

Li Y, Liu Z, Shi P, Zhang JZ. 2010. The hearing gene Prestin unites echolocating bats and whales. Curr Biol 20:R55R56.

Lim DJ. 1986. Functional structure of the organ of Corti-a review. Hear Res 22:117-146.

Liu Y, Cotton JA, Shen B, Han XQ, Rossiter SJ, Zhang SY. 2010. Convergent sequence evolution between echolocating bats and dolphins. Curr Biol 20:R53-R54. 
Lurie MH, Davis H, Hawkins Jr JE. 1944. Acoustic trauma of the organ of Corti in the guinea pig. Laryngoscope 54: $375-386$.

Matsumura M. 2001. A study on the contact between tectorial membrane and inner hair cell stereocilia in the cochlea. Hokkaido Igaku Zasshi 76:151-154.

Mawhinney WHB, Richardson E, Malcolm AJ. 1984. Control of rapid nitric-acid decalcification. J Clin Pathol 37:14091413.

Morell M, André M. 2009. Ear extraction and fixation protocol. Available from: http://www.lab.upc.es/papers/ Ear_extraction_and_fixation_protocol_LAB.pdf.

Morell M, Degollada E, van der Schaar M, Alonso JM, Delory E, López A, Dewez A, André M. 2007. Comparative morphometry of odontocete ears through computerized tomography. J Mar Biol Assoc UK 87:69-76.

Morell M, Degollada E, Alonso JM, Jauniaux T, Andre M. 2009. Decalcifying odontocete ears following a routine protocol with RDO ${ }^{\circledR}$. J Exp Mar Biol Ecol 376:55-58.

Morisaki N, Nakai Y, Cho H, Shibata S. 1991. Imprints of the tectorial membrane following acoustic overstimulation and kanamycin treatment. Acta Otolaryngol Suppl 486: 19-31.

Nadol JB. 1988. Comparative anatomy of the cochlea and auditory-nerve in mammals. Hear Res 34:253-266.

Neuweiler G, Singh S, Sripathi K. 1984. Audiograms of a South Indian bat community. J Comp Physiol 154:133142.

Oghalai JS, Patel AA, Nakagawa T, Brownell WE. 1998. Fluorescence-imaged microdeformation of the outer hair cell lateral wall. J Neurosci 18:48-58.

Pujol R, Lenoir M, Ladrech S, Trebillac F, Rebillard G. 1991. Correlation between the length of outer hair cells and the frequency coding of the cochlea. In: Cazals $Y$, Demeny L, Horner K, editors. Auditory physiology and perception. New York: Pergamon Press. p 45-52.

Pujol R, Lavigne-Rebillard M, Lenoir M. 1997. Development of sensory and neural structures in the mammalian cochlea. In: Rubel EW, Popper AN, Fay RR, editors. Development of the auditory system. New York: Springer. p 146-192.

Raphael Y, Lenoir M, Wroblewski R, Pujol R. 1991. The sensory epithelium and its innervation in the mole rat cochlea. J Comp Neurol 314:367-382.

Retzius G. 1884. Das Gehorogan der Wirbelthiere: I I . Das Gehorogan der Reptilien, der Vogel, und der Saugethiere. Stockholm: Samson \& Wallin.

Reysenbach de Haan FW. 1957. Hearing in whales. Acta Otolaryngol Suppl 134:1-114.

Richardson WJ, Greene CR Jr, Malme Cl, Thomson DH. 1995. Marine mammals and noise. San Diego, CA: Academic Press.

Roth B, Bruns V. 1992. Postnatal development of the rat organ of Corti. I. General morphology, basilar membrane, tectorial membrane and border cells. Anat Embryol 185: 559-569.

Ruttiger L, Panford-Walsh R, Schimmang T, Tan J, Zimmermann U, Rohbock K, Kopschall I, Limberger A, Muller M, Fraenzer JT, Cimerman J, Knipper M. 2007. BDNF mRNA expression and protein localization are changed in age-related hearing loss. Neurobiol Aging 28: 586-601.

Saito K. 1983. Fine-structure of the sensory epithelium of guinea-pig organ of corti - subsurface cisternae and lamellar bodies in the outer hair-cells. Cell Tissue Res 229:467-481.

Sanderson C, Radley K, Mayton L. 1995. Ethylenediaminetetraacetic acid in ammonium hydroxide for reducing decalcification time. Biotechn Histochem 70:12-18.

Sato M, Leake PA, Hradek GT. 1999. Postnatal development of the organ of Corti in cats: a light microscopic morphometric study. Hear Res 127:1-13.

Sato T, Doi K, Taniguchi M, Yamashita T, Kubo T, Tohyama M. 2006. Progressive hearing loss in mice carrying a mutation in the p75 gene. Brain Res 1091:224-234.

Schuknecht HF. 1993. Pathology of the ear. Philadelphia: Lea \& Febiger.

Schulte BA. 1993. Immunohistochemical localization of intracellular Ca-ATPase in outer hair-cells, neurons and fibrocytes in the adult and developing inner-ear. Hear Res 65:262-273.

Shen YY, Liang L, Li GS, Murphy RW, Zhang YP. 2012. Parallel evolution of auditory genes for echolocation in bats and toothed whales. PLoS Genet 8:e1002788.

Slepecky NB, Cefaratti LK, Yoo TJ. 1992. Type-II and type-IX collagen form heterotypic fibers in the tectorial membrane of the inner-ear. Matrix 12:80-86.

Spoendlin H. 1971. Primary structural changes in the organ of Corti after acoustic overstimulation. Acta Otolaryngol 71: 166-176.

Spongr VP, Flood DG, Frisina RD, Salvi RJ. 1997. Quantitative measures of hair cell loss in CBA and $\mathrm{C} 57 \mathrm{BL} / 6$ mice throughout their life spans. J Acoust Soc Am 101:35463553.

Thomson DH, Richardson WJ. 1995. Marine mammal sounds. In: Richardson WJ, Greene CR, Malme CL, Thomson DH, editors. Marine mammals and noise. San Diego, CA: Academic Press. p 576.

Tolomeo JA, Steele CR, Holley MC. 1996. Mechanical properties of the lateral cortex of mammalian auditory outer hair cells. Biophys J 71:421-429.

Vater M, Kössl M. 2011. Comparative aspects of cochlear functional organization in mammals. Hear Res 273:8999.

Vater M, Lenoir M. 1992. Ultrastructure of the horseshoe bat's organ of Corti. I. Scanning electron microscopy. J Comp Neurol 318:367-379.

Vater M, Siefer W. 1995.The cochlea of Tadarida brasiliensis: specialized functional organization in a generalized bat. Hear Res 91:178-195.

Vater M, Lenoir M, Pujol R. 1992. Ultrastructure of the horseshoe bat's organ of Corti .2. Transmission electron microscopy. J Comp Neurol 318:380-391.

Wever EG, McCormick JG, Palin J, Ridgway SH. 1971a. Cochlea of dolphin .3. Tursiops truncatus-hair cells and ganglion cells. Proc Natl Acad Sci U S A 68:2908-2912.

Wever EG, McCormick JG, Palin J, Ridgway SH. 1971b. Cochlea of dolphin, Tursiops truncatus. 2. basilar membrane. Proc Natl Acad Sci U S A 68:2708-2711.

Wever EG, McCormick JG, Palin J, Ridgway SH. 1971c. Cochlea of dolphin, Tursiops truncatus-general morphology. Proc Natl Acad Sci U S A 68:2381-2385.

Wever EG, Ridgway SH, Palin J, McCormick JG. 1972. Cochlear structure in dolphin, Lagenorhynchus obliquidens. Proc Natl Acad Sci U S A 69:657-661.

Zheng J, Shen W, He DZZ, Long KB, Madison LD, Dallos P. 2000. Prestin is the motor protein of cochlear outer hair cells. Nature 405:149-155. 


\section{SGML and CITI Use Only DO NOT PRINT}

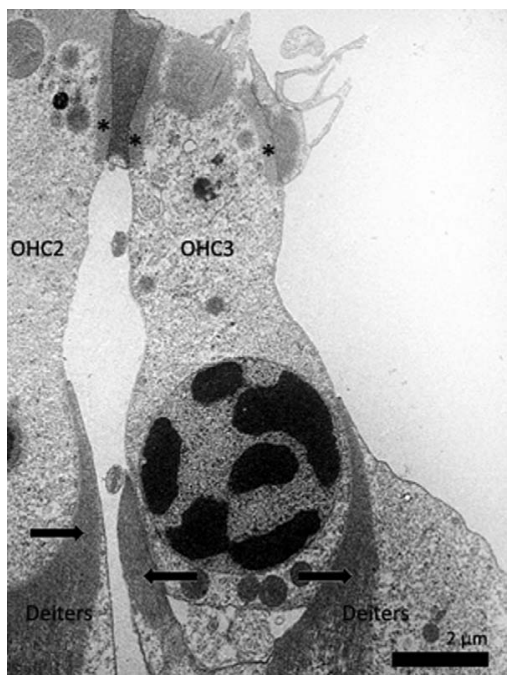

We present scanning (SEM) and transmission (TEM) electron microscopy micrographs of the ultrastructure of the organ of Corti of odontocete species. The species of odontocetes analyzed by TEM presented morphological characteristics, shared with horseshoe bats, suggesting that there has been convergent evolution of sound reception mechanisms among echolocating species. 